\title{
QUALITATIVE AND QUANTITATIVE INTERPRETATION OF HAND-DIGITIZED AEROMAGNETIC DATA FROM IDAH
}

\author{
Robert Bassey Umera \\ Department of Physics \\ Arthur Jarvis University
}

\begin{abstract}
Qualitative and Quantitative interpretation of hand-digitized aeromagnetic data from Idah has been carried out by applying forward and inverse modeling technique. Qualitatively, wavelength and amplitudes of source bodies reveal lithologic contrast, basement structure and sedimentary magnetization contrast. The maximum depth to top of the magnetic source body obtained is $16.8 \mathrm{~m}$ and minimum depth is $0.5 \mathrm{~m}$. The anomalous bodies' total magnetic intensity ranges from a minimum negative peak value of $-153.5 \mathrm{nT}$ to maximum value of $162.7 \mathrm{nT}$. Susceptibility values obtained reveals the presence of rocks such as granite, diabase, olivine-diabase, basalt/gabbro, quartzite and diorite. Results obtained shows that hand-digitized data competes favorably with computer digitized data
\end{abstract}

Keywords - Basement complex; Anomaly; Rock units; granite, diabase, olivine-diabase, basalt/gabbro, quartzite, diorite; suprabasement; Magnetic; Modeling; Susceptibility; basic igneous rocks

\section{INTRODUCTION}

Magnetometry is a potential field method of geophysical survey whose basic task in prospection geophysics is to differentiate the subsurface according to its magnetic properties. Its operative physical property is magnetic susceptibility. Magnetic survey carried out on air is normally termed aeromagnetic survey. It is a common type of geophysical survey that employs the use of a magnetometer toed behind an aircraft. The principle of the survey is similar to that carried out on land (ground magnetic survey) except that it allows coverage of larger area for regional reconnaissance. The end result being an aeromagnetic map, nowadays digitized using computer tools, upon which interpretation is made. The main use of any aeromagnetic data and their derivative maps in mineral prospecting is to make geological deduction from them Dobrin \& Savit, (1988). This article however looks at the interpretation of hand digitized aeromagnetic map with a view of showing its effectiveness in interpreting aeromagnetic data.

\author{
Odong Peter \\ Earth Sciences \\ Arthur Jarvis University
}

\section{THE STUDY AREA}

Fig. 1.0 Geology map of the study area after Obiora et. al., (2006)

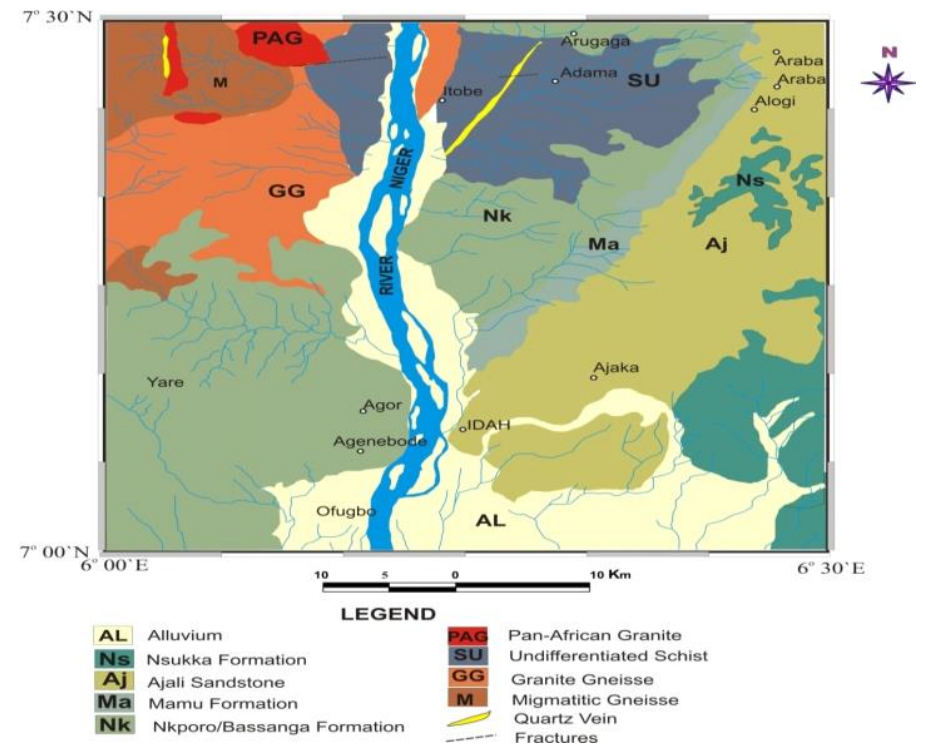

Idah is a town in Kogi state, Nigeria, which lies between latitude $7^{\circ} 00, \mathrm{~N}$ and $7^{0} 30, \mathrm{~N}$ and longitude $6.00 \mathrm{E}$ and 6.30.E. Geologically, the study area (figure 1.0) is located partly in Anambra basin and partly within the basement complex of South Western Nigeria. The geology of Nigeria is dominated by crystalline and sedimentary rocks both occurring approximately in equal proportions Woakes et. al, (1987).

The crystalline rocks are made up of Precambrian basement complex and the phenerozoic rocks which occur in the eastern region of the country and the north central part of Nigeria. The Precambrian basement rocks in Nigeria consist of the migmatite, gneissic-quartzite complex dated archean to early proterozoic (2700-2000ma). Other units include the NE-SW trending schist belts mostly developed in the western half of the country and the grantoid plutons of the older granite suit dated late proterozoic to early phanerozoic $(750$ - n450 Ma). Kogi, (2005) reported that the eastern flank of the state is on 


\section{International Journal of Engineering Applied Sciences and Technology, 2021 \\ Vol. 5, Issue 10, ISSN No. 2455-2143, Pages 55-59 \\ Published Online February 2021 in IJEAST (http://www.ijeast.com)}

the alluvium (youngest and most recent sedimentary rocks) and other sedimentary rocks which form part of cretaceous to recent sediments of Nigeria. The crystalline complex contain economic minerals such as Iron-Ore, gem-stone, quartz, feldspar and other associated minerals while the pan Africa granite/older granite contains cassiterite, tantalite, columbite, gemstones and other associated minerals.

Some researchers such as Daniel et. al, (2016), Obi et. al, (2010), Kayode (2006), Folami, (1992), have carried out interpretation of aeromagnetic data using one or more combined methods including forward and inverse modeling. This article seeks to show the effectiveness of hand-digitized data in aeromagnetic data interpretation.

\section{MATERIALS AND METHOD}

Aeromagnetic survey in Nigeria is mostly conducted by the Nigeria Geological Survey Agency (NGSA), the end result being a sheet of aeromagnetic map for the surveyed area and or computer digitized magnetic data for the surveyed area. Idah sheet (267) was surveyed at a flight line spacing of $500 \mathrm{~m}$ and terrain clearance of $80 \mathrm{~m}$. Magnetic instrument used include air plane, toed magnetometer, recording altimeters, magnetometer stinger and digital data acquisition system, track recovery system, magnetic compensation unit and Doppler navigation system. IGRF was applied to remove geomagnetic gradient from the data.

The map was hand-digitized using a clearly calibrated ruler, HB pencil and white sheet of paper. The format of data presentation is shown in table 1.0

Table 1.0: format of hand-digitized

\begin{tabular}{|l|l|l|l|}
\hline$X$ & $Y$ & $Z$ & TMI \\
\hline 1.0 & 0 & 0 & 7025 \\
\hline 1.2 & 0 & 0 & 7030 \\
\hline
\end{tabular}

The $\mathrm{Y} \& \mathrm{Z}$ are set to zero while $\mathrm{x}(\mathrm{cm})$ is the corresponding value on the calibrated ruler that touches the magnetic contour line whose value is to be recorded. TMI (nT) is the total magnetic intensity. Care was taken throughout the course of hand-digitizing the map to avoid parallax error. Although hand digitization is adjudged by some geoscientists such as Bath, (1974) to be the most elementary least efficient method of digitization, however, if carefully done, its accuracy is comparable to other sophisticated methods. Also handdigitization method does not in anyway alter the recorded values of the total magnetic intensity (TMI) on the map, thus TMI values used for the forward and inverse modeling reflects the true values obtained during field measurement. Handdigitized data were modeled using Potent v4.11.06 geophysical software. Qualitative and quantitative data interpretation was carried out.

\section{RESULT AND DISCUSSION}

\section{RESULTS}

Profile method of magnetic data presentation was adopted. Five profiles were taken on the sheet across areas of interest as shown in profile 1-5. Summary of the modeled profiles are shown in table 2.0

\section{DISCUSSION}

Qualitatively, wavelength and amplitude of an anomaly are useful tools in magnetic data interpretation. Wavelength of an anomaly is proportional to the depth of the magnetic source body that produces it. More correctly, depth is related to the horizontal distance of the slope of the anomaly Dale, (2001). Thus long wavelength is characterized by deep seated bodies while short wavelength depicts shallow sources. Amplitude on the other hand is proportional to magnetic susceptibility contrast in the rocks and it decreases with increasing distance. Amplitudes are generally divided into categories of hundreds of $\mathrm{nT}$, tens of $\mathrm{nT}$ and ones of $\mathrm{nT}$. Lithologic variation in magnetic basement or presence of igneous rocks within the sedimentary section, generally produce anomalies with the highest amplitude Dale, (2001). In summary, anomalies with amplitude of the order:

100 snT maybe related to lithologic variation in basement or igneous rocks with the sedimentary section, 10snT maybe related to basement structure (suprabasement), $1 \mathrm{snT}$ are related to sedimentary magnetization contrast.

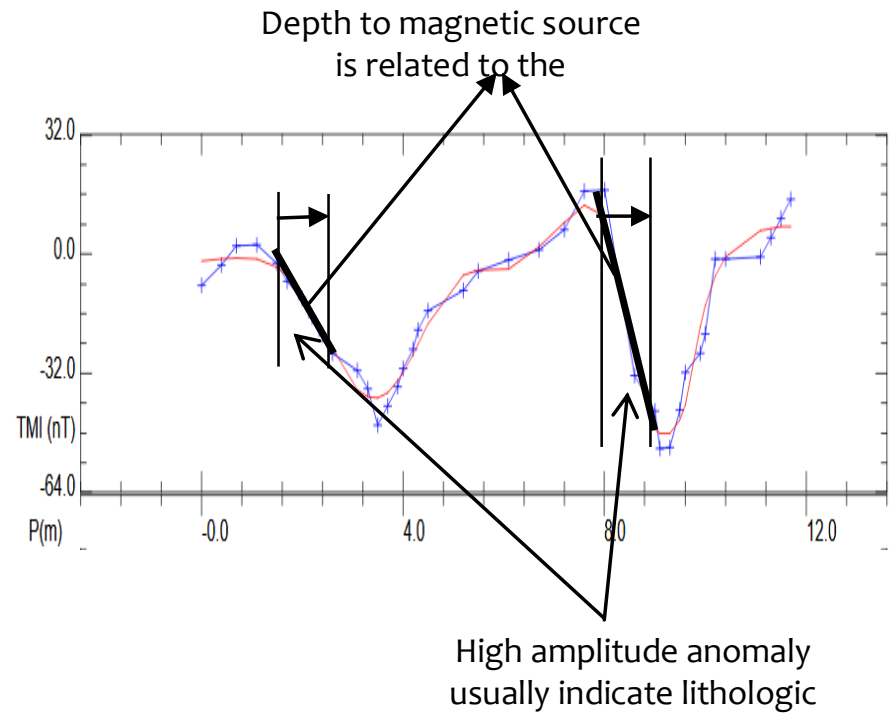

Figure 2.0: profile 5 showing the characteristics features of the 
Consequently, a quick view of profiles 5 interms of wavelength reveals the characteristics features of the causative bodies as labeled in figure 2.0. Interms of order of amplitudes, profile 1 has a total magnetic intensity with minimum peak value of $-153 \mathrm{nT}$ and a maximum positive peak value of $162.7 \mathrm{nT}$. This is related to lithologic variation in basement or igneous rocks with the sedimentary section. Profiles $2,3,4 \&$ 5 has minimum negative values of $-28.0 \mathrm{nT},-70.2 \mathrm{nT},-80 \mathrm{nT}$, and $-56 \mathrm{nT}$, respectively to maximum positive peak values of 32.0nT, 41.2nT, 60.2nT, and 32.0nT, respectively. These are related to suprabasement. In general, the magnetic intensity of the area ranges from minimum value of $-153.5 \mathrm{nT}$, to maximum value of $162.7 \mathrm{nT}$. The area is marked by both high and low magnetic signatures which could be attributed to several factors such as variation in depth, difference in magnetic susceptibilities, difference in lithology and degree of strike Obiora, et. al, (2016).

Qualitatively, susceptibility values - $-0.0025,0.00262$, $0.0565,0.0298,0.0654,0.0040,0.0829$ suggest the presence of rock types such as granite, diabase, olivine-diabase, basalt/gabbro, quartzite and diorite respectively. Other negative susceptibility values indicate the presence of rock types that are diamagnetic in nature. Diamagnetic materials are characterized by constant small negative susceptibilities only slightly affected by changes in temperature (Encyclopedia Britannica, 2019). Table 2.0 gives summaries of results obtained with corresponding rock types.

\section{Profile 1}

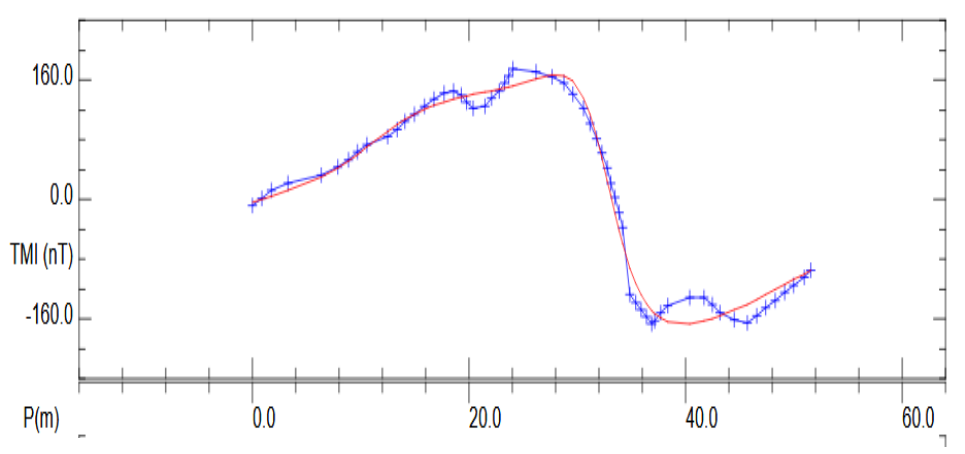

Profile 2

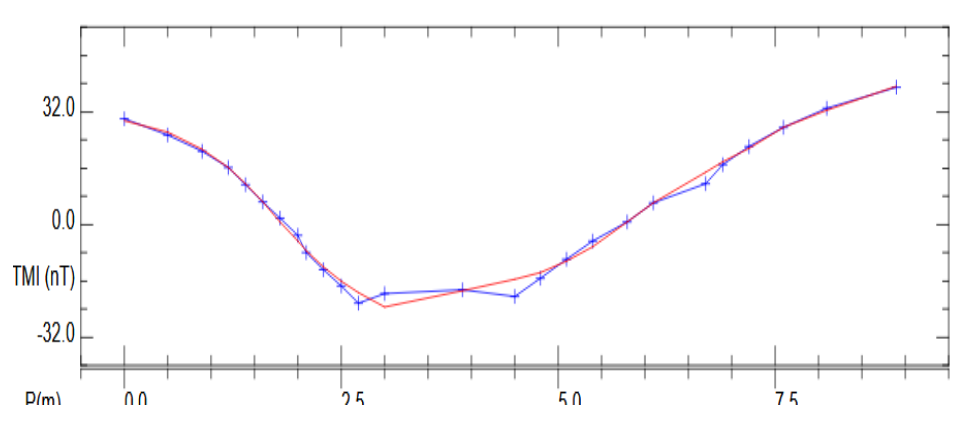

\section{Profile 3}

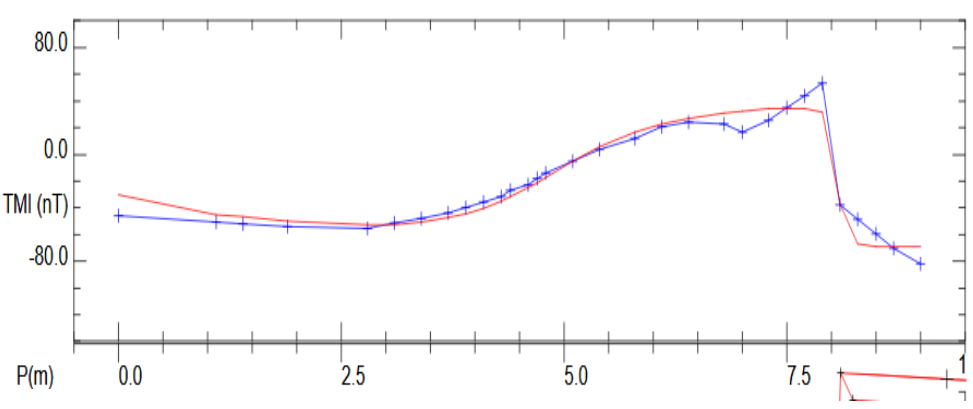

Profile 4

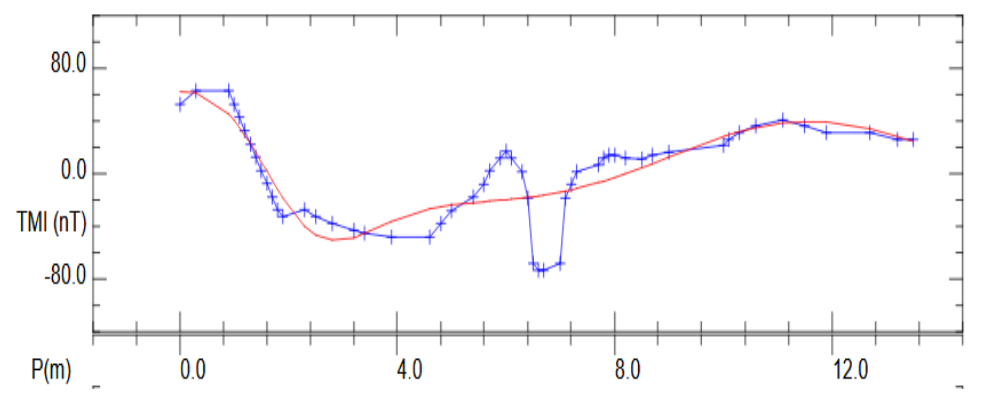

Profile 5

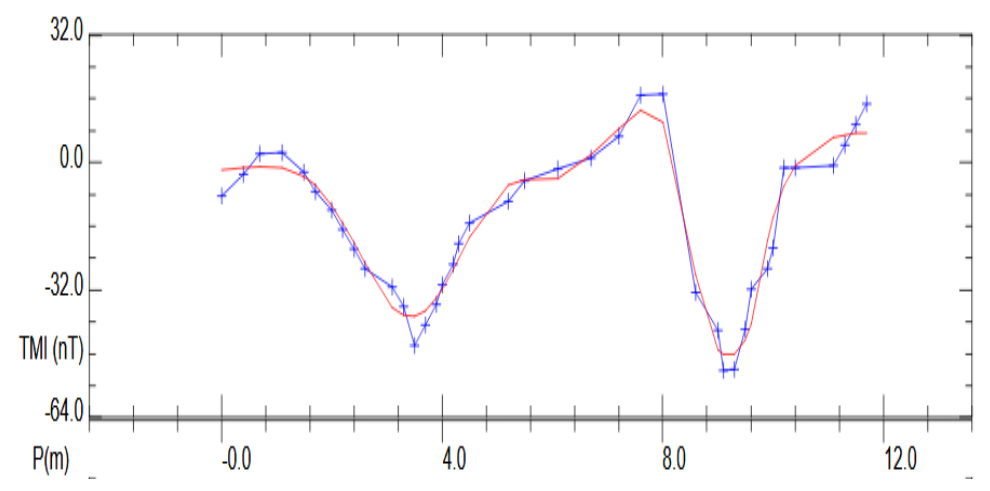


Table -1 Experiment Result

\begin{tabular}{|c|c|c|c|c|c|c|c|c|c|c|}
\hline Profiles & $\mathbf{X}(\mathbf{m})$ & $\mathbf{Y}(\mathbf{m})$ & $\begin{array}{l}\text { No. of } \\
\text { bodies }\end{array}$ & $\begin{array}{l}\text { K values } \\
\text { (SI) }\end{array}$ & Dept.(m) & $\begin{array}{l}\text { Type of } \\
\text { body }\end{array}$ & $\begin{array}{l}\text { Dip } \\
\text { (deg.) }\end{array}$ & $\begin{array}{l}\text { Plunge } \\
\text { (deg) }\end{array}$ & $\begin{array}{l}\text { Strike } \\
\text { (deg.) }\end{array}$ & $\begin{array}{l}\text { Suspected rock type } \\
\text { based on value }\end{array}$ \\
\hline \multirow[t]{4}{*}{1} & 8.0 & -26.1 & 4 & -0.0031 & -5.8 & Slap & $\begin{array}{l}-1.8 \\
\end{array}$ & -18.4 & -88.3 & (Diamagnetic) \\
\hline & 22.0 & -25.8 & & 0.1134 & -4.9 & Slap & 3.9 & -0.6 & -86.1 & Ultramafic rocks \\
\hline & 34.0 & 1.8 & & 0.0829 & -4.0 & Slap & -5.9 & 2.5 & 94.3 & Diorite \\
\hline & 47.0 & -14.2 & & -0.2696 & -16.8 & Rect. prism & 11.2 & 2.1 & -2.1 & (Diamagnetic) \\
\hline \multirow[t]{3}{*}{2} & 4.1 & -0.4 & 3 & $\mathbf{0 . 0 3 9 3}$ & -0.8 & Slap & -1.0 & -1.0 & 4.6 & (Unknown) \\
\hline & 6.9 & -0.9 & & -0.1144 & -1.1 & Slap & 0.1 & -0.1 & 0.8 & (Diamagnetic) \\
\hline & 1.6 & -0.5 & & 0.0040 & -0.0 & Rect. prism & 0.2 & 0.0 & 88.1 & Quartzite \\
\hline \multirow[t]{4}{*}{3} & 9.4 & 0.0 & 4 & -0.0017 & -0.6 & Slap & 3.0 & 2.4 & 88.1 & (Diamagnetic) \\
\hline & 6.8 & 0.1 & & -0.0173 & -0.6 & Slap & -2.2 & 2.0 & 89.9 & (Diamagnetic) \\
\hline & 1.0 & -0.8 & & 0.0157 & -2.0 & Slap & 1.5 & 1.0 & -0.5 & (Unknown) \\
\hline & 5.0 & 0.2 & & -0.0171 & -0.5 & Slap & 0.7 & 1.0 & 0.5 & (Diamagnetic ) \\
\hline \multirow[t]{2}{*}{4} & 2.5 & -1.5 & 2 & 0.0654 & -0.5 & Sphere & 0.0 & 0.0 & -90.0 & Basalt/gabbro \\
\hline & 11.3 & -1.5 & & 0.6148 & -5.7 & Sphere & 0.0 & 0.0 & -90.0 & (Unknown) \\
\hline \multirow[t]{4}{*}{5} & 0.2 & -2.3 & 4 & -0.0025 & -0.6 & Dyke & 1.0 & 1.0 & 7.0 & Granite (Diamagnetic) \\
\hline & 3.7 & -2.9 & & -0.00262 & -0.7 & Dyke & 0.0 & 0.0 & 0.9 & Granite (Diamagnetic) \\
\hline & 7.3 & -2.0 & & -0.0565 & -0.7 & Dyke & -8.0 & -0.0 & -178.9 & Diabase (Diamagnetic) \\
\hline & 10.0 & -2.7 & & 0.0298 & -0.9 & Dyke & -11.8 & -9.1 & -33.0 & Olivine -Diabase \\
\hline
\end{tabular}

\section{CONCLUSION}

Hand-digitized aeromagnetic map of Idah has been analyzed using forward and inverse modeling technique. Qualitative and quantitative interpretation of obtained results competes favorably with those submitted by Obiora et. al., (2006). Anomalous bodies recorded include granite, diabase, olivinediabase, basalt/gabbro, quartzite and diorite. Susceptibility values with negative sign suggest that the area is characterized by diamagnetic materials.

\section{ACKNOWLEDGMENT}

The authours are grateful to God Almighty for the success of this work. We are also grateful to the Nigeria geologic Survey Agency for providing the Map upon which hand digitisation was carried out

\section{REFERENCES}

Bath M (1974) spectral analysis in geophysics. Elsevier publication co., Amsterdam

Daniel N.O. et al. (2016) Interpretation of Aeromagnetic data of Idah area in North central Nigeria using combined methods
Dobrin, M. B. \& Savit, C.H. (1998) Introduction to geophysical prospecting. McGraw - Hill Book Co. Inc. New york

Egboka, B.C.E., Nwakwor G.I, and Orajaka, I.P. Implications of palæo-and neotectonics in gully erosion -prone areas of south eastern nigeria. (1990). Natural Hazards, 3:219-220 231

Folami, S. L. (1992) Interpretation of aeromagnetic anomalies in Iwaraja area, south western Nigeria, Journal of Mining. Geol 17: 179 - 176

Kayode, J.S. (2006) Ground magnetic study of Jeda - Iloko area Southwestern Nigeria and its geologic interpretation, Federal University of Technology, Nigeria.

Kogi state ministry of solid mineral development (Now ministry of special duties) (2005), Kogi state mineral Investment prospects, p49

Lowrie, W. (1997). Fundamental of applied geophysics, Cambridge, University Press.

Obi, D. A., Okereke, C.S., Obei, B.C. and George, A. M. (2010). Aeromagnetic modeling of subsurface intrusives and its implication on hydrocarbon evaluation of the lower Benue trough. Nigeria European Journal of Scientific Research, 47(3): 347. 
Published Online February 2021 in IJEAST (http://www.ijeast.com)

Schneidegger, A.D. , and Ajakaiye, D.E. Mass movement in hilly areas (with examples from Nigeria. National hazards 9.191 -196 (1994). (C) Clawer academic publication, printed in Netherland

Telford, W.M., Geldart, L.P. \& Sheriff, R.E. (1990). Appled geophysics ( $2^{\text {nd }}$ Edition), Cambridge, University Press, Cambridge.

Woakes, M., Ajibade C.A., Rahaman, M.A. (1987) Some metallogenic features of the Nigeria Basement, Journal of Africa science vol., pp. 655 - 664 